\title{
ŠKOLOVANJE JURE (FRA PETRA) KORDIĆA
}

\author{
Rudolf BARIŠIĆ \\ Hrvatski studiji Sveučilišta u Zagrebu \\ Borongajska cesta 83d \\ HR - 10000 Zagreb \\ E-pošta: rbarisic@hrstud.hr
}

UDK 27-789.32(497.6)"17/18"
929 Kordić J.
Izvorni znanstveni rad
Primljeno: 1. svibnja 2015.
Prihvaćeno: 10. lipnja 2015.

\section{Sažetak}

U razdoblju od 1785. do 1847. djelovanjem zaklade, koju je na poticaj Augustina Botoša Okića osnovao Josip II., financirano je školovanje više od 250 klerika Franjevačke provincije Bosne Srebrene. Na samom početku ciljevi ove akcije bili su sasvim drugačiji. Njezinom primarnom zadaćom trebalo je biti stvaranje dijecezanskoga klera koji bi bio neovisan o franjevcima i na osnovi kojega bi se uspostavila redovita crkvena hijerarhija po uzoru na zapadne dijelove Europe. U sklopu tih planova Jure Kordić je zajedno $s$ još 11 mladića bio poslan na školovanje u Zagreb. U radu se donosi što je moguće preciznija rekonstrukcija njegova boravka ondje i tijeka njegova obrazovnog kurikuluma koji su stavljeni u kontekst događaja koji će dovesti do propasti ovih planova. Kordić se nakon dovršetka studija vratio u Bosnu i stupio u franjevački red uzevši redovničko ime Petar, te je kasnije vršio različite službe, najčešće vezane uz kreševski samostan.

Ključne riječi: Jure (fra Petar) Kordić, biskupski licej, Zagreb, zaklada Josipa II., studij teologije. 
Fra Petar Kordić, stariji (1765.-1835.) ${ }^{1}$ ne pripada u one franjevce Bosne Srebrene čiji su život i rad predstavljali predmet historiografskih istraživanja. Njegovo se ime ne spominje niti u Jelenićevoj Biobibliografiji, niti u onoj koju je sastavio Anto Kovačić, a natuknicu o njemu ne donosi ni Hrvatski franjevački biografski leksikon. ${ }^{2}$ Tek je $\mathrm{u}$ novije vrijeme osnovne podatke iz njegova redovničkog života u Leksikonu hercegovačkih franjevaca sumirao Robert Jolić. ${ }^{3}$ Najprije je u kreševskom samostanu dvije godine bio nedjeljni i svetkovinski propovjednik (1800.1802.), a potom pet godina župnik u Ružićima (1802.-1807.). Nakon toga vraća se u kreševski samostan gdje uzastopce vrši službe gvardijana (1809.-1812.) i meštra novaka (1812.1817.). Svojevrstan vrhunac njegove redovničke službe predstavlja dvostruko obavljanje dužnosti provincijala Bosne Srebrene (1817.-1820. i 1826.-1829.). Između njih je obavljao druge različite dužnosti u upravi Provincije poput definitora ili vizitatora.
Umro je na samu Novu godinu 1835. u samostanu u Kreševu. ${ }^{4}$

Kako je vidljivo iz ovih kratkih biografskih crtica, Kordić je najznačajnije razdoblje svoga redovnišstva proveo u periodu kada su bosanskohercegovački prostor $s$ jedne strane pogađale prirodne nepogode poput epidemije kuge koja je harala 1813.-1817., a značajan su odjek imali i politički događaji na njezinim granicama: francuska okupacija hrvatskih zemalja južno od rijeke Save i srpski ustanci. Međutim, $s$ druge strane upravo u periodu u kojemu on obavlja dužnost provincijala, odnosi unutar Bosne Srebrene doživljavaju svojevrsnu stabilnost, zahvaljujući ponajprije djelatnosti apostolskoga vikara Augustina Miletića. Kordić je doživio i prijepore između Provincije i Miletićeva prethodnika Grge Ilijića Varešanina, a potom i početak sukoba s Rafom Barišićem, no oba ta događaja prošla su bez njegova većeg angažmana. ${ }^{5}$ Kordić po nečemu ipak predstavlja značajnu iznimku u uku-

1 Nije poznat točan datum Kordićeva rođenja. Ponegdje se kao godina navode 1767. ili 1768. Npr. AndRIJA Nikić, Lučonoše naše vjere i uljudbe, mrtvoslovnik hercegovačkih fratara, Franjevačka knjižnica i arhiv, Mostar, 2004., str. 141 bilježi da je Kordić umro u 68. godini života, što bi značilo da je rođen jedne od navedenih godina. Međutim, prilikom stupanja u novicijat samostana u Kreševu kao datum rođenja i krštenja upisan je travanj 1765. Usp. RoBert Jolić, Novicijat hercegovačkih franjevaca, RECIPE Knj. 3, Hercegovačka franjevačka provincija Uznesenja BDM - Naša ognjišta, Mostar - Tomislavgrad, 2009., str. 45-46.

2 Natuknica "Kordić, Petar", u: Hrvatski franjevački biografski leksikon, Zagreb, 2010. str. 307 odnosi se na Petra Kordića ml. (1823.-1896.) najpoznatijega po graditeljskoj djelatnosti. Obojica su potjecali iz istoga mjesta (Sretnice pokraj Mostara) koje je tada pripadalo župi Brotnjo.

3 Usp. Robert Jolić, Leksikon hercegovačkih franjevaca, RECIPE Knj. 9, Hercegovačka franjevačka provincija Uznesenja BDM, Mostar, 2011., str. 195. Odavde su preuzeti podatci koji se iznose dalje u tekstu.

4 Arhiv franjevačKoga samostana u Fojnici (dalje: ASFS), I., "Fojnicensia", Kutija 4, br. 17, Necrologium Provinciae, ad diem.

5 O situaciji u Bosni Srebrenoj početkom 19. st. u širem društvenom kontekstu opširno piše SRećKo M. DžAjA, Katolici u Bosni i zapadnoj Hercegovini na prijelazu iz 18. u 19. stoljeće - Doba fra Grge Ilijića Varešanina (1783-1813), Kršćanska sadašnjost, Zagreb, 1971. 
pnoj povijesti Bosne Srebrene. Radi se o njegovu školovanju.

Kao i većina njegove subraće, najveći je dio školovanja proveo u inozemstvu. Dva momenta ovoga dijela njegove biografije privlače posebnu istraživačku pažnju: kao prvo, pripadao je jednoj od prvih generacija kojima je odredištem bio Zagreb, umjesto dotadašnje prakse da se klerike šalje u neku od franjevačkih provincija u Italiji, te kao drugo, nije se školovao za redovničko, nego za dijecezansko svećenstvo. Dok je praksa odlaska klerika na školovanje na prostor Habsburške Monarhije postala stalnom i potrajala sve do 1843. godine, a s njom se nastavilo i kasnije, pokušaj da se obrazovanjem bosanskohercegovačkih mladića stvori kler koji bi bio neovisan o franjevačkoj provinciji Bosni Srebrenoj ostao je neuspješnom epizodom. Kako će se vidjeti u nastavku teksta, Kordić je bio samo jedan u skupini od 12 mladića školovanih u navedenu svrhu, ali trenutačno raspoloživa i dostupna arhivska građa koja se čuva u Nadbiskupijskom arhivu u Zagrebu sugerira da je upravo on najuspješnije polazio ukupan kurikulum koji je u njegovu slučaju moguće makar ugrubo skicirati i povući vremenske odrednice. Prije nego li se izloži tijek njegova školovanja, treba ukratko opisati u kakvim je okolnostima došlo do uvjeta da Habsburška Monarhija zamijeni Italiju kao glavno odredište bosanskih klerika, te ideje o etabliranju dijecezanskoga svećenstva umjesto tada dominirajućih franjevaca.
Dobivši uz pomoć habsburškoga dvora imenovanje za apostolskoga vikara u Bosni, Augustin Botoš Okić uputio se ujesen 1784. iz Rima, gdje je bio posvećen za naslovnoga biskupa trapezopolitanskog, u Beč gdje je u nekoliko navrata bio primljen u audijenciju kod kralja i cara Josipa II. ${ }^{6}$ Time se uključio u protuosmanlijske planove koje je Josip II. kovao zajedno s ruskom caricom Katarinom II. Zauzvrat je dobio rješenje jednoga od gorućih pitanja koja su mučila Katoličku crkvu na bosanskohercegovačkom prostoru toga doba. Franjevci Bosne Srebrene bili su glavni i gotovo isključivi nositelji pastoralne skrbi nad bosanskohercegovačkim katolicima što je bila zadaća kojoj su podređivali svu svoju energiju i materijalna sredstva. U takvim okolnostima obrazovanje budućih svećenika ovisilo je o pomoći iz inozemstva, ponajprije od franjevačkih provincija smještenih u današnjoj Italiji. Zbog više razloga iz toga je procesa proizlazilo mnogo poteškoća i Bosna Srebrena trsila se naći neko trajnije i stabilnije rješenje, pri čemu Okić nije bio iznimka.?

Iskoristivši priliku koja mu se pružila apostolski je vikar iznio navedeni problem Josipu II. koji se pokazao spremnim pružiti traženu pomoć. Formalnom odlukom Kraljevskoga ugarskog namjesničkog vijeća (dalje KUNV) od 10. siječnja 1785 . od novčanih sredstava namijenjenih za uzdržavanje hodočasničkih mjesta u Svetoj Zemlji, formirana je zaklada čijim se kamatama ubuduće trebalo

6 Za okolnosti ovoga izbora i kronologiju boravka u Rimu i Beču usp. Isto, str. 112.

7 O nekim, osobito negativnim, aspektima boravka franjevačkih klerika na školovanju u Italiji usp. Isto, str. 140-141. 
financirati školovanje i boravak bosanskih klerika. ${ }^{8}$

Ovime je započelo razdoblje od šest desetljeća u kojima će preko 250 klerika Bosne Srebrene svoje obrazovanje dijelom ili u cijelosti pohađati negdje na području Ugarske i Hrvatske. Zanimljivo je, ipak, kako je prvotna nakana imala sasvim suprotne ciljeve. Josip II. je za uključivanje Bosne u Habsburšku Monarhiju nastojao provesti određene pripreme koje su za cilj imale $s$ jedne strane pridobivanje podrške svih slojeva lokalnoga pučanstva, ali s druge strane i provođenje reformi na tragu onih koje su već trajale u područjima pod njegovom vlašću. Lojalnost bosanskih katolika, kao i njihova spremnost da prihvate habsburšku vlast bili su, kao uostalom i prije, neupitni, ali se tijekom 18. st. drastično bila izmijenila njihova socijalna slika. U sklopu nje više nego ikada prije, ulogu društvene, pa prema tome i političke elite, preuzeli su franjevci Bosne Srebrene. Takva njihova uloga bila je daleko od toga da bude lišena ikakvih osporavanja. Glavni smjer takvih pokušaja nije dolazio s osmanlijske strane, nego iz redova samih franjevaca - pretenzije za vodećom ulogom gajili su pojedinci iz redova apostolskih vikara.

Složeno pitanje tih odnosa ovom se prilikom može tek ilustrirati navođenjem nekih osnovnih razvojnih crta. Nakon što su Mirom u Srijemskim Karlovcima 1699. godine povučene konkretne granice između Osmanlijskoga Carstva i Habsburške Monarhije, u vidu zakašnjeloga provođenja reformi zadanih saborom u Tridentu, papinstvo je potražilo rješenje kojim bi za bosanskohercegovačko područje bio postavljen stalno rezidentni biskup. Taj je cilj postignut svojevrsnim kompromisom zbog kojega je osnovan Apostolski vikarijat, što je u određenoj mjeri moglo zadovoljiti tri zainteresirane strane. ${ }^{10}$ Rimska je kurija sa svoje strane dobila biskupa koji je stalno boravio u osmanlijskoj Bosni. ${ }^{11} \mathrm{Za}$ isto je područje bio zainteresiran i bečki Dvor koji je poziva-

8 Tekst navedene odluke donosi Julijan Jelenić, Izvori za kulturnu povijest bosanskih franjevaca, Zemaljska štamparija, Sarajevo, 1913., str. 57. Okolnosti u kojima je došlo do osnivanja zaklade detaljnije su prikazane u: Rudolf BARIšıć, "Početak školovanja bosanskih klerika na učilištima u Habsburškoj Monarhiji", u: Pavao Knezović - Marko Jerković (ur.), Zbornik o Mati Zoričiću: Zbornik radova sa znanstvenog skupa, Knjižnica Tihi pregaoci - Hrvatski studiji Sveučilišta u Zagrebu, Zagreb, 2012., str. 179-201.

9 Socijalne promjene u strukturi bosanskohercegovačkih katolika 18. st. prikazuje SREĆко M. DžajA, Konfesionalnost $i$ nacionalnost Bosne i Hercegovine - predemancipacijsko razdoblje 1463.-1804., ZIRAL, Mostar - Sarajevo, 1999., osobito str. 166-192.

10 Okolnosti osnivanja vikarijata opisuje S. M. DžAJA, Katolici u Bosni i zapadnoj Hercegovini, str. 104-105. J. JelenIĆ, Izvori, str. 97 donosi citat u kojemu su navedene njegove granice: "Amplitudo longitudinis, et latitudinis Vicariatus Apostolici Bosnensis, non potest juste metiri, nec describi (...). Communes tamen termini sunt = Ex parte Sclavoniae, et Confinio Imperii flumen Savus, nobis Sava. Ex parte Serviae (...) flumen Drina. Ex parte Dalmatiae mons Prologh (...). Ex parte Croatiae Mons dictus Plissivicza."

11 U tekstu se za promatrani prostor koriste odrednice "Bosna"/"bosanski" i "Bosna i He rcegovina"/"bosanskohercegovački". U potonjem slučaju radi se o uporabi u smislu današnjih granica. Tijekom razdoblja o kojemu se piše u ovom radu pojam "Bosna" mogao je označavati ili administrativnu jedinicu unutar Osmanlijskoga Carstva ili prostor or- 
jući se na tradicije i prava ugarskohrvatskih kraljeva smatrao kako se njegovo patronatsko pravo predlaganja i potvrđivanja biskupa proteže i na Bosnu (čije se područje i dalje de iure u dijecezanskom pogledu nalazilo pod jurisdikcijom biskupa u Đakovu). Organiziranjem apostolskoga vikarijata kao svojevrsnoga biskupskog provizorija, pravo patronata nije bilo dovedeno u pitanje, nego spretno zaobiđeno. $\mathrm{Na}$ sličan se način postupilo i s pitanjem statusa Bosne Srebrene. Formalno je nastavila vrijediti ranija praksa prema kojoj je uprava provincije imala pravo predlaganja jednog ili više kandidata za biskupsku čast. ${ }^{12}$ Uslijedio je duži period u kojemu se održavala opisana ravnoteža. Problemi i nesuglasice koji su, dakle, mogli izbiti bili su oni između apostolskih vikara s jedne i provincije Bosne Srebrene s druge strane. Njihovo je polazište uvijek bilo identično: nastojanje apostolskih vikara da biskupsku čast i vlast izdignu iznad realno prave snage - Bosne Srebrene. ${ }^{13}$

Srž tih prijepora predstavljalo je pitanje mjerodavnosti nad župama. Kako je Bosna Srebrena jedina raspolagala kadrovima kojima je moglo biti povje-

ganizirane katoličke hijerarhije bilo u vidu franjevačke provincije Bosne Srebrene, bilo $\mathrm{u}$ vidu Apostolskoga vikarijata. Opseg tih administrativnih jedinica niti u jednom od tih slučajeva nije se podudarao sa suvremenim bosanskohercegovačkim granicama. U svima njima se, pak, pod terminom "Bosna"/"bosanski" podrazumijeva i zapadni dio Hercegovine. Prema tomu bilježenje "Bosna" bez Hercegovine ne treba promatrati kao vid ekonomičnosti (a kamo li površnosti) u pisanju, nego želju da se naglasi ova administrativna dimenzija korištenja toga pojma. Primjerice, izraz "bosanski klerici" koji će se više puta koristiti u nastavku teksta ne treba tumačiti u smislu da su svi potjecali s područja geografske Bosne, nego da su u jurisdikcijskom pogledu pripadali ili Bosni Srebrenoj, ako su bili franjevci ili Apostolskom vikarijatu u Bosni, ako su bili kandidati za svjetovno svećenstvo.

12 Navedeno se pravo pobliže objašnjava u Dekretu Kongregacije za širenje vjere (Propagande) od 3. lipnja 1635. kojim su rješavane nesuglasice između Bosne Srebrene s jedne i bosanskih, skradinskih i smederevskih biskupa s druge strane, te neka druga pitanja. U jednoj od točaka nalazi se sljedeće: "Treće, o biskupima u provinciji Bosni Srebrenoj koji se ne bi smjeli promaknuti prije nego se čuju franjevci spomenute provincije, Sveta je Kongregacija odgovorila: 'Neka se obdržava ono što je uobičajeno, tj. da provincijal ili definitorij pro tempore predlože nekoliko redovnika Svetomu Ocu, koji će ili jednoga između predloženih ili nekoga drugoga promaknuti kako prosudi da se u Gospodinu dolikuje."' Izvorni latinski tekst nalazi se u: Julijan Jelenić, "Spomenici kulturnoga rada bosanskih Franjevaca (1437.-1878.)", u: Starine JAZU, Knjiga 36, Zagreb, 1918., str. 110. U tradiciji bosanskih franjevaca ovaj se tekst često tumačio kao dodjeljivanje isključivoga prava predlaganja kandidata upravi Bosne Srebrene, premda je iz samoga teksta jasno da se radi o privremenoj (pro tempore) praksi, koja nije dokidala papino pravo da imenuje i kandidata mimo prijedloga provincijala i definitorija. Ostavljajući ovdje po strani crkveno-pravno tumačenje ovih odnosa, neosporno je da su sve do Augustina Botoša Okića apostolski vikari prilikom svoga izbora na tu čast uživali podršku Bosne Srebrene.

13 Međusobni odnosi između apostolskih vikara i Bosne Srebrene u biti su i dalje bili u glavnoj mjeri određeni odlukama koje je donijela Rimska kurija 1618. i 1660. godine oko pitanja mjerodavnosti apostolskih vizitatora koji su tijekom 17. st. bili slani na područje pod osmanlijskom vlašću između ostaloga s ciljem dijeljenja sakramenta potvrde ili svećeničkoga ređenja. Detaljnije o ovim dekretima: Julijan Jelenić, Kultura i bosanski franjevci, I., Prva hrvatska tiskara Kramarić i M. Raguz, Sarajevo, 1912., str. 184-187. 
reno upravljanje župama, apostolski su se vikari uvijek nalazili u donekle podređenom položaju. Za afirmiranje vlastitoga položaja i pretvaranje vikarijata u "pravu" biskupiju kronično im je nedostajao svećenički kadar koji ne bi bio ovisan o franjevcima. Okolnosti u kojima se odvio Okićev izbor za apostolskoga vikara, konkretno činjenica da je on potvrđen $u$ Rimu bez ikakvoga udjela Bosne Srebrene, učinile su prvi korak prema spomenutoj afirmaciji. Drugi se trebao dogoditi nakon habsburškog pripajanja Bosne, a spomenutom zakladom Josip II. je već želio stvoriti neke uvjete za to.

Zbog svega navedenog odluka KUNV-a o osnivanju zaklade za školovanje bosanskih klerika predstavlja specifikum u povijesti katoličanstva u Bosni, a što je uočio još Džaja. Dva su bitna elementa: prvi je adresiranje teksta isključivo na apostolskoga vikara, a drugi je izostavljanje pridjeva religiosus (redovnički) u frazi "pro educando juniore clero Bosnens". Već je na tom mjestu očita nakana bečkoga Dvora da djelovanjem zaklade stvori svjetovno svećenstvo, odnosno da ostvari jedan od bitnih uvjeta za uvođenje redovite crkvene hijerarhije. Nije pri tom bila riječ o habsburškom nepovjerenju u bosanske franjevce kao takve, nego nastavku crkvene politike koja je na ugarsko-hrvatskom prostoru tijekom 18. st. uglavnom istisnula redovnike iz uprave župama. ${ }^{14}$

Sam početak djelovanja zaklade, odnosno datum i identitet prvih stipendista još su uvijek slabo poznati. Prema podatcima koji se nalaze u dopisu KUNV-a vezanim za osnivanje zaklade, Okić je izjavio kako na raspolaganju ima sedmoricu kandidata za dobivanje stipendije, a koji bi mogli pristići u Monarhiju do početka studenoga $1785 .{ }^{15}$ Njihova konkretna imena i drugi biografski podatci nisu sačuvani i upitno je ikakvo konkretiziranje s Okićeve strane. $\mathrm{Na}$ to upućuje dopis Karla Pálffyja, bliskoga suradnika Josipa II. od 3. svibnja 1785. u kojemu se preciziraju kriteriji za buduće stipendiste: zreliji mladići, sa završenom gramatikom i humaniora, te bez položenih redovničkih zavjeta. Budući da je bila donesena odluka o ukidanju generalnoga sjemeništa u Zagrebu, kao privremeni smještaj im je određen tamošnji samostan franjevaca Provincije sv. Ladislava. ${ }^{16}$

Prvi sačuvani podatci o klericima nalaze se u financijskom izvješću koje je u kolovozu 1788. sastavio gvardijan zagrebačkoga samostana Kajetan Auker. ${ }^{17}$ Iz njega jasno proizlazi da su

14 O tomu Dubravka Božıć Bogović, "Odnos svjetovnog biskupijskoga klera prema franjevcima u istočnoj Slavoniji i Srijemu u prvim desetljećima 18. stoljeća", u: TatjanA Melnik (ur.), Zbornik o fra Antunu Bačiću (Radovi znanstvenog skupa), Hrvatski institut za povijest - Podružnica za povijest Slavonije, Srijema i Baranje - Zavičajni muzej Našice - Franjevački samostan sv. Antuna Padovanskog u Našicama - Franjevački samostan Presvetoga Trojstva u Slavonskom Brodu, Slavonski Brod - Našice, 2013., str. 47-60.

15 Usp. J. Jelenić, Izvori, str. 57.

16 Isto, str. 58.

17 Nadbiskupijski arhiv u Zagrebu (dalje: NAZ), Spisi Nadbiskupskog duhovnog stola (Officium dioecesanum) (dalje: NDS [OD]), 845/1788. Prvi broj predstavlja oznaku protokolarnog unosa, a drugi godište. 
prvi klerici u Zagreb stigli početkom i tijekom ljeta 1786. kada je ubilježen dolazak njih trojice. Međutim, od njih se samo jedan (Paškal Kopić, st.) u Zagrebu zadržao dulje od godinu dana. Sva trojica su, pak, bili zavjetovani franjevci, čime očito nisu bili ispunjeni kriteriji koje je Pálffy zadao apostolskom vikaru. Tijekom 1787. godine $\mathrm{u}$ nekoliko su navrata stigli novi stipendisti koje će izvori kasnije najčešće bilježiti odrednicom clerici saeculares - kandidati za svjetovno svećenstvo, koji su trebali postati nukleusom buduće redovite crkvene hijerarhije, nakon što bi bosanskohercegovačko područje potpalo pod habsburšku vlast. Pojam clericus u navedenom je razdoblju prvenstveno označavao mlađu osobu koja se tek pripremala za svećenički poziv. Ova se skupina u izvorima javlja pod zbirnim nazivom clerici saeculares. Objašnjenje leži u tomu što su ovi klerici, kao kandidati za svjetovno svećenstvo bili smješteni u franjevački samostan, izmiješani s franjevačkim kandidatima, pa je saeculares služio kao razlikovanje. U daljnjem tekstu će se stoga koristiti skupni pojam "svjetovni klerici".

Prvi je 10. siječnja 1787. stigao Toma Pravdić, a za njim 13. ožujka Josip Zečević. Prvoga dana rujna stigla je najveća skupina u sastavu: Stjepan Vidović, Ivan Alović, Josip Vasiljević, Pavao Nikolić, Anto Nikolić, Filip Zubčević, Pavao Botoš Okić i Jure Kordić. U veljači 1788. pristigao je i Josip Tomić, ml., imenjak i nećak Josipa Tomića Hadžije, franjevca čijom je zaslugom Bosna Srebrena 1783. go- dine dobila sultanov ferman kojim su joj potvrđena sva stara prava i povlastice koje su bile privremeno ukinute 1765. godine. ${ }^{18}$ Uza svjetovne klerike stigla su još dvojica franjevačkih (Franjo Dobretić i Blaž Kulašević), ali ne iz Bosne, nego iz Italije gdje su se prethodno nalazili na školovanju i njihov se dolazak u Zagreb nije poklapao sa željama apostolskoga vikara.

Kako većina ovih klerika kasnije nije postala svećenicima ili nije djelovala u Bosni, podatci o njihovim godinama ili mjestu rođenja poznati su samo u manjem broju slučajeva i to obično na osnovi šturih podataka koje su davali sami o sebi. Iz istoga razloga nemoguće je utvrditi na koji su način i prema kojim kriterijima bili odabrani i poslani u Zagreb. Sve franjevačke kronike veoma slabo pokrivaju upravo ovo razdoblje, a njihovi naknadni nastavljači očito nisu nailazili na pisane tragove koje bi zatim unijeli. Neki se odrazi ovoga događaja, vjerojatno sačuvani usmenom tradicijom, mogu naći u kasnijoj literaturi franjevačke provenijencije. Točno stotinu godina nakon što je Okić postao apostolskim vikarom i vršio pregovore s Josipom II., Martin Nedić bilježi sljedeće: "Dobivši starješine ovu pomoć poslaše u prekosavske države dvanaest mladića, koji su odstojali godinu kušanja (annum novitiatus) a nisu još učinili svečanih zavjeta reda (vota solemnia ordinis); od ovih dvanaest mladića samo su ostala dvojica u redu: Petar Kordić i Pavo Alović, a ona druga desetorica odbaciše svitu redovničku, te njeki postaše častnici

18 Osnovni podatci o tomu nalaze se u: S. M. DžAja, Katolici u Bosni i zapadnoj Hercegovini, str. 124-125. 
u vojsci a njeki svjetski svećenici."19 Tri godine poslije Mijo Vjenceslav Batinić opisuje kako je Okić umro: "ostavivši svoj spomen u rečenoj zakladi, kojom se medjutim za njegovo doba ne okoristiše bosanski franjevci, pošto je odmah s početka dvanaest klerika u Zagrebu smještenih prešlo u svietovno stanje i nigda se više ne vratilo u domovinu." ${ }^{20}$ Promotre li se oba upisa, u oči najprije upada razlika: prema Nediću dvojica članova ove skupine su na kraju (p)ostali franjevcima, dok su prema Batiniću svi napustili red. U pravu je Nedić. Naime, Petar Kordić i Pavao Alović nalaze se na Aukerovu popisu kao Jure Kordić i Ivan Alović. ${ }^{21}$ Nadalje, taj popis sadrži 11 imena koja uza se nemaju odrednicu fra ili $p$. Stvar je u tome što je posljednji u skupini svjetovnih klerika, Luka Marijanović, u Zagreb došao tek u lipnju $1792 .{ }^{22}$ Nediću i Batiniću je zajedničko predstavljanje ove skupine klerika kao svojevrsnih franjevačkih renegata.
Pri tome je prvi ponešto precizniji pa govori kako su spomenuti proveli novicijat, ali nisu položili zavjete. Ovu tvrdnju ipak treba dovesti u pitanje. Ulazak u novicijat (odnosno oblačenje habita) bilježio se, naime, zasebno u odnosu na zavjetovanje, a također su se od 1783. godine morali bilježiti i podatci o glasovanjima (obično njih 3) kojima se odlučivalo o (ne) pripuštanju kandidata zavjetovanju. ${ }^{23}$ Sve da je Okić u skladu s dobivenim uputama KUNV-a i spriječio njihovo polaganje zavjeta, nema razloga zbog kojeg bi neubilježenim ostalo njihovo stupanje u novicijat, osobito ne u svim slučajevima. U svakom slučaju, konkretni podatci o mjestu, vremenu i načinima odabira članova ove skupine trenutačno nisu poznati, pa tako ni slučaj Jure Kordića.

Sumirajmo ukratko dosad navedeno. Očekujući pobjedu u predstojećem sukobu s Osmanlijama, Josip II. je i na crkvenom planu pripremao

19 Martin Nedić, Stanje Redodržave Bosne Srebrene poslje pada Kraljevstva Bosanskog pak do okupacije, Fortuna, Zagreb, 2011., str. 88-89. Riječ je o pretisku djela originalno tiskanog 1884.

20 Mijo Vjenceslav Batinić, Djelovanje franjevaca u Bosni i Hercegovini za prvih šest viekova njihova boravka, svezak III. Provincija (1700-1835). Tiskom dioničke tiskare, Zagreb, 1887., str. 169. U tradiciji Bosne Srebrene zabilježena je i veća brojka. Primjerice Arhiv franjevačKog samostana u Kraljevoj Sutjesci (dalje: AFSKS) Klevetajući i sablažnjujući spisi, Kut. 1., Svež. 3 sadrži jedno pismo od 21. kolovoza 1841. upućeno iz Fojnice zagrebačkom biskupu Jurju Hauliku u kom se navodi sljedeći opis: "Quemadmodum certissimo experimento edoceor dum tempore (...) Josephi II. in Austriacas Provincias 14 nostrates improfessi (istaknuo autor!) pro studiis missi, solum duo reversi, bene notus Zagrabiae Illustritati Vestrae Petrus Kordich, et alter Paulus Allovich professionem religiosam emiserunt (...). alii vero 12 quidam Martem secuti, quidam bene sibi visa officia amplexati, nonnulli statui Ecclesiastico saeculari extra Patriam semet addixerunt, quidam item minus contenti praesenti vitae conditione, ipso Deo vindice in barathrum desperationis acti misere vitam terminarunt, atque ita pia expectatione suam fefellerunt Provinciam."

21 Usp. NAZ NDS (OD) 845/1788.

22 Usp. NAZ NDS (OD) 993/1792. Int.

23 Ta je odluka upisana u knjizi oblačenja novaka kreševskoga samostana. Usp. R. Jolıć, Novicijat, str. 40. 
pripajanje Bosne, želeći je urediti po uzoru na reforme provođene $u$ samoj Monarhiji. Može se zaključiti da su te mjere išle za ciljem da se istiskivanjem bosanskih franjevaca iz upravljanja župama stvore preduvjeti za uspostavljanje redovite crkvene hijerarhije. Taj se cilj nastojao ostvariti nedovođenjem svećenika iz drugih dijelova Monarhije, nego stvaranjem potrebnoga klera iz redova domaćih mladića. Uloga samoga apostolskog vikara pri svemu tome ostaje unekoliko nejasnom. S jedne strane, iako je ideja o svećeničkim kandidatima koji ne bi bili i redovnici bila naznačena već u samoj odluci od 10 . siječnja 1785., Pálffy ga je u svibnju morao ponovno podsjetiti na nju što pokazuje da je Okić pripremao slanje franjevačkih klerika, što su prva trojica pristiglih u Zagreb i bila. S druge strane, nakon opomene Okić se angažirao oko ispunjavanja postavljenih kriterija i njegovim su zalaganjem poslana dvanaestorica mladića bez redovničkih zavjeta. Nakon habsburškoga neuspjeha u ratu od daljnjeg se slanja svjetovnih klerika odustalo, što također onemogućava nedvojben odgovor na pitanje: je li se i Okić nadao uspostavi redovite crkvene hijerarhije ili je ispunjavajući habsburške zahtjeve samo nastojao ne izgubiti pravo na korištenje zaklade koje je Bosna Srebrena, kako je već istaknuto, zadržala više od pola stoljeća.

Složenost će se ovih odnosa prelomiti upravo na sudbinama ovih klerika, ali presudan utjecaj na njihovu daljnju sudbinu imala su pitanja upravo obrazovne naravi. Odlukom Josipa II. 1783. godine bila su ukinuta redovnička visoka učilišta i škole. ${ }^{24}$ Obrazovanje budućih svećenika, kako dijecezanskih, tako i redovničkih, u potpunosti je pod svoj nadzor trebala staviti država. Ovaj se cilj planirao ostvariti osnivanjem Generalnih sjemeništa od kojih se jedno trebalo nalaziti u Zagrebu. Školski kurikulum za buduće pripadnike klera u Habsburškoj Monarhiji toga doba bio je organiziran na način da su kandidati nakon 6 godina gimnazijskoga obrazovanja (obično 4 razreda gramatike i 2 razreda humaniorâ), polazili 2 godine studija filozofije, a nakon toga još 4 godine studija teologije. U nastavi nižih razina (gramatika i humaniorâ) kao nastavni jezici služili su njemački, mađarski i hrvatski, dok su se filozofija i teologija slušale na latinskom jeziku. Bosna Srebrena je načelno u onom razdoblju koje bi njezini kandidati proveli uoči i tijekom novicijata nastojala da oni u što većoj mjeri usvoje osnove latinskoga jezika. ${ }^{25}$ Zbog čitava niza objektivnih okolnosti u praksi je to veoma često izrazito slabo funkcioniralo i klerici su u inozemstvo odlazili bez dovoljna predznanja, što je ondje produžavalo njihov boravak. U trenutku kada je Pálffy ponavljao upute Okiću, dakle u svibnju 1785., zagrebačko je generalno sjemenište već bilo ukinuto. Opravdano pretpo-

24 Detaljnije o tomu: Franjo Emanuel HošKo, Franjevačke visoke škole u kontinentalnoj Hrvatskoj, Kršćanska sadašnjost, Zagreb, 2002., str. 22; IsTI, Slavonska franjevačka učilišta, Kršćanska sadašnjost, Zagreb, 2011., str. 281, bilj. 178.

25 O tomu više u: S. M. DžAJA, Katolici u Bosni i zapadnoj Hercegovini, str. 136-139; R. Jolić, Novicijat, str. 12-19. 
stavljajući da klerici nemaju potrebno predznanje latinskoga jezika, s habsburške je strane bilo zaključeno da se skupinu mora smjestiti negdje na hrvatskom govornom području, dok ne savladaju latinski u dovoljnoj mjeri da više razine mogu pohađati negdje na području ostatka Ugarske, gdje su se nalazila ostala generalna sjemeništa. Kao najprikladnije odredište ostavljen je Zagreb, a kako se klerike željelo zadržati u skupini, za njihov je smještaj određen franjevački samostan koji je pripadao Provinciji sv. Ladislava. Okolnosti provođenja ove odluke pokazale su se u mnogočemu presudnima za daljnji tijek školovanja ove skupine, pa tako i Jure Kordića.

Odluka da se njihov smještaj povjeri franjevcima, donesena je jednostrano i očigledno bez prethodnih konzultacija $s$ njima. ${ }^{26}$ Boravak klerika bio je praćen i s financijskim poteškoćama, na koje su se kasnije nadovezale one vezane uz nadzor nad njima. $U$ kombinaciji svih navedenih čimbenika najupadljiviju karakteristiku cjelokupna boravka ove skupine u Zagrebu predstavljale su nesuglasice između njih i zagrebačkih franjevaca. Svojevrsno svjedočanstvo o tomu već je i spomenuto Aukerovo izvješće u kojemu su prezentirani podatci prema kojima je zagrebački samostan na raznorazne potrepštine pri uzdržavanju klerika potrošio iznos koji je premašivao onaj koji je bio isplaćivan na ime njihovih stipendija. ${ }^{27}$ Kordićevo se ime u nje- mu javlja dva puta. Za njegovu hranu je od 1. rujna 1787. do 31. srpnja 1788. (kada je izvješće i sastavljano) bilo potrošeno 110 forinti, a u dva navrata je plaćano za popravak njegove obuće: 30. siječnja 1788. u iznosu od 1 forinte i 8 groša, te već 28. svibnja iste godine, kada je na obuću Kordića i još dvojice klerika potrošen iznos od 2 forinte i 15 groša. Dakako, brojni troškovi poput nastavnoga materijala, svijeća, usluga pranja odjeće i slično navedeni su zbirno. To obuhvaća i lijekove, ali nije moguće utvrditi je li Kordić i od čega bolovao. Na taj način saznajemo za datum njegova dolaska u Zagreb, ali vrlo malo o njegovoj svakodnevici, kao i o tomu kako je tekao njegov školski put. Odnosi između zagrebačkih franjevaca i njihovih gostiju iz Bosne veoma su brzo postali napeti i od tada će se pitanje discipline, prema izvorima, nametati kao glavni problem.

Premda bi se očekivalo da će glavnim kamenom spoticanja biti svjetovni status većine klerika, pravi problemi izbili su djelovanjem dvojice klerika koji su bili franjevci. Obojica su u Zagreb stigli nakon boravka u Italiji gdje su, unatoč kratku vremenu provedenu na školovanju, već bili zaređeni za svećenike. Prvi je u Zagreb u prosincu 1787. stigao Blaž Kulašević. Kako zbog zime nije mogao nastaviti putovanje prema Bosni, bio je primljen u zagrebački samostan, a na proljeće je njegov povratak bio one-

26 Dovoljno je usporediti datume: Pálffy je ovu odluku priopćio Okiću u pismu datiranom 3. svibnja 1785., što svjedoči da je ona donesena i nešto ranije, a prema Aukerovu pisanju on je, kao gvardijan, za nju saznao tek 30. svibnja.

27 Prema Aukerovu izračunu svota koju je samostan utrošio na uzdržavanje bosanskih klerika premašivala je dobivena sredstva za nešto više od 240 forinti. Usp. bilj. 17. 
mogućen izbijanjem rata. ${ }^{28}$ Od veće važnosti za kasniji tijek događaja bio je dolazak Franje Dobretića u ožujku 1788. Ovaj će klerik postati jednom od središnjih ličnosti tijekom idućih godina, a zagrebački će ga franjevci uvijek spominjati u negativnom kontekstu kao glavnoga začetnika svih disciplinskih poteškoća. Ostavljajući po strani prosudbe o tomu je li njegov karakter bio pozitivan ili negativan, nedvojbeno je kako se Dobretić uspio nametnuti kao svojevrstan vođa cjelokupne skupine klerika iz Bosne, a da mu je to dobrim dijelom pošlo za rukom zbog njegova boljeg uvida u način funkcioniranja struktura uključenih u proces stipendiranja. To pokazuje već i njegov dolazak. Dok je Kulašević, kako je rečeno, u Zagreb došao planirajući nastaviti put kući, a na popisu stipendista našao se tek kasnije spletom ratnih okolnosti, dolazak u Zagreb je od početka predstavljao Dobretićev plan kao i nalaženje načina da ondje ostane. ${ }^{29}$ Veoma brzo po svom dolasku počeo je pokazivati neke neuredne sklonosti među kojima se posebno isticala sklonost alkoholu i kartanju. U idućem periodu Auker je uputio još nekoliko žalbi na Dobretićev račun, a potom su svi bosanski klerici (i franjevački i svjetovni) 14. studenoga 1788. sastavili pismo i uputili ga biskupu Maksimilijanu Vrhovcu, u kojem su optužili zagrebačke franjevce da su Dobretiću, Kulaševiću i svjetovnom kleriku Josipu Zečeviću ukrali novac. Ostali klerici, među kojima i Kordić, svojim su potpisima nastupili kao svjedoci. ${ }^{30}$ Ove su pritužbe odbačene, ali su posljedično vodile $\mathrm{k}$ novim sukobima. U veljači iduće godine zagrebački su franjevci sastavili novu predstavku u kojoj se nalazi popis različitih prekršaja koje su činili klerici. ${ }^{31}$ Ovaj spis zavrjeđuje nešto veću pozornost, ne samo zbog toga što se u njemu zasebno spominje i Kordić, nego i zato jer pokazuje kako među klericima nije uvijek vladala sloga.

Optužbe su podijeljene u 12 točaka u kojima se najčešće spominje Dobretić, ovaj put i u kontekstu fizič-

28 Vojne operacije na rijeci Savi otpočele su 9. veljače 1788. O Dubičkom ratu opširnije: Robert Skenderović, "Bilješke Josipa Paviševića o protuturskom ratu Josipa II. 1788.-1791. godine", u: Ana Pintarić - Franjo Emanuel Hoško (ur.), Zbornik o Josipu Paviševiću, Filozofski fakultet Sveučilišta J. J. Strossmayera - Hrvatska Franjevačka provincija sv. Ćirila i Metoda, Osijek - Zagreb, 2006., str. 127-140, osobito str. 130 gdje se nalazi kratka bibliografija radova o ovoj temi i ukazuje na njegovu razmjernu zanemarenost unutar hrvatske historiografije.

29 Cijeli se slučaj može rekonstruirati na osnovi više spisa koji se čuvaju pod signaturom NAZ NDS (OD) 1219/1788. osobito prema jednoj predstavci o cijelom slučaju koju je zagrebačkom biskupu Maksimilijanu Vrhovcu 14. listopada 1788. iznio Auker. Ukratko, Dobretić je najprije iz Italije pisao Okiću tražeći premještaj u Zagreb, a kada je bio odbijen, poslužio se varkom da od generala franjevačkoga reda dobije dozvolu za posjet rodbini u Bosni. Pravac kretanja prilagodio je tako da putuje preko Zagreba, a po dolasku u Zagreb započeo je upućivati molbe na različite adrese, s ciljem da mu se odobri stipendija iz zaklade. Posredovanjem samoga bana u tomu je napokon i uspio. Ostaje nejasnim na koji je način Dobretić uopće saznao za postojanje stipendije i kako je došao u kontakt s banom.

30 Usp. NAZ NDS (OD) 1372/1788.

31 Usp. NAZ NDS (OD) 334/1789. 
kih obračuna. Ispostavilo se da su optužbe za krađu iznesene na račun zagrebačkih franjevaca lažne, a neki od klerika su posvjedočili da je cijeli slučaj izmislio upravo Dobretić. Ljutit zbog toga, on je krenuo u osvetnički pohod, čemu su posvećene tri točke. Najprije je pretukao Stjepana Vidovića, a zatim izudarao Ivana Alovića. Potom je zajedno s Kulaševićem i Zečevićem napao i Paškala Kopića. Međutim, ovom prilikom im se suprotstavio upravo Kordić pa se Kopić uspio izvući. $\mathrm{Na}$ to mu je Dobretić zaprijetio kako će ga ubiti iz pištolja kada ga nabavi. Ovo nam sugerira kako je Kordić očito bio čovjek znatne fizičke snage, barem u odnosu na spomenutu trojicu. Cijeli je slučaj završio izbacivanjem Dobretića, Kulaševića i Zečevića iz samostana. ${ }^{32}$ Njihovim udaljavanjem nisu prestale međusobne trzavice preostalih klerika. Kordić je s još sedmoricom 23. prosinca 1789. potpisao novo pismo upućeno biskupu Vrhovcu u kojemu se žale na postupke dvojice klerika. ${ }^{33}$ Pojedini su među njima bili izbacivani iz samostana ili su ga svojevoljno napuštali. Prema jednom izvješću koje je u srpnju 1790. sastavio tadašnji vikar samostana u Zagrebu Benvenut Orlić, u tom su trenutku ondje još uvijek stanovala šestorica klerika, među njima i Kordić. ${ }^{34} \mathrm{U}$ idućim go- dinama su i oni postupno prelazili u privatan smještaj i sudeći prema izvješću o školskom uspjehu podnesenom na kraju školske godine 1792./1793. svi su svjetovni klerici živjeli po privatnim stanovima. ${ }^{35}$

Kako je vidljivo iz gore navedenoga, prvih šest godina Kordićeva boravka u Zagrebu u izvorima su ponajviše zastupljene u pogledu različitih disciplinskih poteškoća. Koliko se može procijeniti, on sam u njima nije igrao značajniju ulogu i spominje se relativno rijetko. Opravdano je pretpostaviti da se nalazio među posljednjim svjetovnim klericima koji su napustili smještaj u okvirima samostanske zajednice. Sve to sugerira da njegovo ponašanje nije iskakalo iz postavljenih okvira. Jedino poimenično apostrofiranje predstavlja ga u prilično pozitivnom svjetlu, jer je zaštitio jednoga kolegu pred napadom ostalih. Međutim, svi su ovi događaji imali utjecaja i na njegovu sudbinu. $\mathrm{Na}$ napuštanje samostana, vjerojatno više nego li situacija s ostalim klericima iz Bosne, presudnu ulogu imalo je njegovo nepripadanje franjevačkom redu. Zagrebački su se franjevci, kojima je prihvat i smještaj bosanskih klerika bio jednostrano nametnut, u svjetlu iskustava s jozefinističkim pritiscima, tomu očito opirali. ${ }^{36}$ Brojni problemi između klerika i njihovih

32 Odluka je donesena na sjednici Duhovnoga stola 19. veljače 1789. Usp. NAZ NDS (OD) 360/1789.

33 Pismo je sastavljeno na hrvatskom jeziku i čuva se pod: NAZ NDS (OD) 1912/1789.

34 Usp. NAZ NDS (OD) 839/1790. Int.

35 Usp. NAZ NDS (OD) 1107/1793. Int.

36 Za potpunije razumijevanje utjecaja kao i vremenskoga trajanja crkvenoga aspekta jozefinizma, značajni su radovi Emanuela Franje Hoška, i to s dvostrukoga gledišta. Kao prvo, Hoško dokazuje da jozefinizam nije završio smrću Josipa II. i njegovim povlačenjem većine svojih ranijih odluka, nego razlikujući tri faze smješta njegov kraj u 1855. 
domaćina vjerojatno su makar dijelom bili uvjetovani i promijenjenim okolnostima smještaja. Zbog ratnih je potreba samostan na Kaptolu 9. kolovoza 1788. bio prenamijenjen u vojnu bolnicu, koja je ondje ostala sve do siječnja 1793., a povratak franjevaca, koji su do tada boravili u zgradi bivšega kapucinskog samostana, dogodio se tek 6 . kolovoza $1793 .{ }^{37}$ Ako ne već ranije, a onda su upravo tada posljednji među svjetovnim klericima prešli u privatan smještaj, vjerojatno pod izgovorom da, kako nisu bili redovnici, franjevci nemaju obveza prema njima. U navedenom izvješću spominje se kako je klerik Grgo Šerkić ostao stanovati u samostanu zato što je bio zavjetovani franjevac.

Isto izvješće sadrži i prve konkretne podatke o školovanju klerika, o čemu u ranije nastalim izvorima nije bilo riječi. U takvom kontekstu podatci prezentirani u izvješću stvaraju dodatnu zbrku, jer pokazuju izrazitu neujednačenost, budući da su klerici polazili različite obrazovne razine, čak i u slučajevima kada su zajedno došli u Zagreb. Najdalje je pri tom dogurao upravo Kordić koji je zajedno s Josipom Zečevićem tada završio drugu godinu studija filozofije. ${ }^{38}$ Polaznici su polagali gradivo iz četiriju predmeta.
Najveća ocjena koju se moglo ostvariti bila je "izvrstan" (eminens), za kojom je slijedio "prvi red" (prima classis). Njih dvije su garantirale prolazak. "Drugi red" (secunda classis) je formalno bio smatran padom, ali premda je Kordić iz jednoga ispita ostvario upravo taj uspjeh dopušten mu je upis studija teologije. Tek je "treći red" (tertia classis) označavao vrlo loš uspjeh na ispitu i za sobom povlačio upute mjerodavnih tijela o tomu kako polaznik mora ponavljati cjelokupno gradivo iz toga predmeta. ${ }^{39}$

Već je navedeno kako se od klerika očekivalo da nastavu polaze prema shemi $4+2+2+4$. Pod uvjetom da je $s$ nastavom započeo odmah ujesen 1787. i da je redovito polazio nastavu, Kordić je 1793. godine trebao dovršavati drugi razred humaniorâ. Činjenica da izvješće navodi da je tada dovršio drugu godinu studija filozofije jasno otkriva da je u njegovu slučaju učinjena iznimka. Objašnjenje ovoga slučaja leži u usporedbi s napredovanjem Josipa Zečevića, jedinoga klerika koji je sa studijem došao jednako daleko kao i Kordić. Glavni uvjet za upis i humaniorâ, a osobito studija filozofije, predstavljalo je poznavanje latinskoga jezika, a upravo tomu je bilo usmjereno nastojanje u trima

kada je konačno sklopljen konkordat između Habsburške Monarhije i Svete Stolice. Kao drugo, autor jozefinizam promatra u kontekstu ostalih sličnih strujanja onodobne Europe (galikanizam, febronijanizam, rišerizam i osobito jansenizam) predstavljajući na taj način dvije njegove bitne odrednice: obnovno katoličanstvo (Reformkatholizismus) i izgradnju državne Crkve kao svojevrsni cezaropapizam (Staatskirchentum). Usp. Franjo Emanuel HošKo, "Franjevci u Slavoniji i Podunavlju u vremenu kasnog jozefinizma", u: Croatica christiana periodica, god. 29, br. 55, Zagreb, 2005., str. 115-161, osobito str. $115-118$.

37 Usp. PašKal Cvekan, Kaptolski franjevci: kulturno povijesni prikaz djelovanja franjevaca kroz 770 godina na Kaptolu u Zagrebu, (vlastita naklada), Zagreb, 1990., str. 69.

38 Usp. bilj. 35.

39 U citiranom izvješću jedan treći red je ostvario Franjo Dobretić. 
bosanskim samostanima. Za Zečevića je poznato da je čak neko vrijeme boravio u novicijatu samostana u Fojnici, a premda je odatle bio izbačen, našao je načina da se nađe na popisu klerika koje je Okić poslao u Zagreb. ${ }^{40}$ Kordić prije dolaska u Zagreb nije stupio u novicijat, ali upravo ovi podatci o školovanju pružaju snažne indicije da je neko vrijeme boravio u Kreševu, pripremajući se za to.

Osim nejednakih razina koje su polazili klerici, postoji još jedan naizgled kontradiktoran podatak. Kordićevo se ime, naime, tijekom iste šk. god. 1792./1793. spominje i među polaznicima prve godine studija teologije u biskupskom liceju u Zagrebu. Prema ovom je izvješću u drugom semestru spomenute školske godine polazio gradivo iz kolegija hermeneutike Novoga zavjeta, a na ispitu je postigao prvi red. ${ }^{41} \mathrm{U}$ nedostatku ikakvih drugih podataka trenutačno nije mo- guće dati objašnjenje ovoga presedana. Iduće šk. god. 1793./1794. njegovo se ime ponovno nalazi na popisu slušača prve godine studija teologije koji je kasnije polazio redovito. $\mathrm{U}$ prvom semestru prve godine nastavio je slušati hermeneutiku Novoga zavjeta, a osim toga polazio je još i nastavu iz grčkoga jezika i iz oba ispita ostvario prvi red, što će i postati njegovom uobičajenom ocjenom. ${ }^{42} \mathrm{U}$ drugom semestru odslušao je gradivo iz kanonskoga prava. ${ }^{43}$

Studij druge godine tijekom prvoga semestra šk. god. 1794./1795. polazio je redovito. Slušao je crkvenu povijest, ${ }^{44}$ te hebrejski jezik i hermeneutiku Staroga zavjeta. ${ }^{45} \mathrm{U}$ drugom semestru se razbolio. $\mathrm{O}$ naravi bolesti nisu sačuvani nikakvi podatci, ali ona ga je omela u redovitom pohađanju nastave tako da je polagao samo privatne, a ne i javne ispite. ${ }^{46}$ Javne je ispite iz navedenih predmeta polagao

40 Usp. R. Jolić, Novicijat, str. 83 gdje se nalaze podatci o oblačenju, dvama glasovanjima i odluci o kazni koja je donesena 14. siječnja 1785., dakle na dan kada su trebali polagati zavjete. Razlogom izbacivanja bila su učestala bježanja iz samostana. Osim Zečevića u novicijatu su se nalazila još trojica mladića, ali njihova se imena više ne javljaju u kontekstu redovničkoga života. Zečević se u izvorima često javlja i pod prezimenom Dobretić, budući da je odatle bio rodom. Između njega i Franje Dobretića nije postojala rodbinska povezanost.

41 Usp. NAZ Arhiv Nadbiskupskoga bogoslovnog sjemeništa (dalje: NBS), Školska izvješća (dalje: Šk. izv.) 3 za šk. god. 1792./1793., Classificatio Hermenevtarum N. T. pro Secundo Semestri. Zajedno s njegovim ubilježeno je i Zečevićevo ime.

42 NAZ NBS Šk. izv. 4, Auditores Lingvae Graecae \& Hermenevticae Sacrae Novi Testamenti secundum data cum in privatis, tum in publico Examine primo Semestri Anni Scholastici 1793/4. in Classes redacti.

43 Isto, Classificatio Auditorum Juris Canonici in Seminario Cleri junioris Dioecesis Zagrabiensis e publico e privatis $2^{\text {di }}$ semestris 1793/4. Examinibus facta.

44 NAZ NBS Šk. izv. 5, Classificatio Auditorum Historiae Ecclesiasticae in Lycaeo Episcopali Zagrabiensi pro primo semestri Anni Scholastici 1794/5.

45 Isto, Auditores Lingvae Hebraeae et Hermenevticae Sacrae V. T. pro $1^{\circ}$ Semestri Anni Scholastici 1794/5. in Classes redacti.

46 Isto, Classificatio Auditorum Historiae Ecclesiasticae in Lycaeo Episcopali Zagrabiensi facta secundo semestri Anni Scholastici 1794/5. i Isto, Auditores Hermeneuticae Sacrae Veteris Testamenti Secundum data specimina Secundo Semestri Anni Scholastici 1795. in Classes redacti. 
naknadno kao student treće godine u šk. god. 1795./1796. ${ }^{47}$ Iste je godine odslušao i gradivo iz pastoralne $\mathrm{i}$ dogmatske teologije. Cijelo vrijeme ostvarivao je identičan uspjeh: prima classis. ${ }^{48}$ Napokon, 1796./1797. pohađao je četvrtu, posljednju godinu studija tijekom kojega je nastavio slušati gradivo iz dogmatike, te iz moralne teologije. Iz dogmatike je postigao svoj uobičajeni uspjeh, ali je iz moralke u drugom semestru konačno na ispitu dobio ocjenu eminens. Time je dovršio studij i stekao uvjete za svećeničko ređenje, ali o tomu ne postoje podatci u knjizi ređenja Zagrebačke (nad) biskupije. ${ }^{49}$ Zanimljivo je, pak, napomenuti kako je u citiranim školskim izvješćima njegov status bio šaroliko bilježen: nekada uz njegovo ime stoji oznaka pripadnosti Bosanskoj biskupiji (Dioec. Bosnensis), ali je u nekoliko navrata ubilježen i kao franjevac (Franciscanus Bosnensis). To nas dovodi do pitanja njegova statusa.
Iako je prešao u privatan smještaj, Kordić je cijelo vrijeme studija dobivao stipendiju u visini od $200 \mathrm{ft}$. godišnje tako da se u njegovu statusu stipendista ništa bitno nije promijenilo. ${ }^{50}$ Ono što se, pak, drastično izmijenilo bile su okolnosti koje više ni izdaleka nisu bile identične onima kakve su bile u trenutku kada je Kordić došao u Zagreb. Rat kojim je bosanskohercegovački prostor trebao doći pod habsburšku vlast, a gdje bi onda Kordić bio dio prve etape u formiranju redovite dijecezanske strukture, završio je neuspjehom i Mirom u Svištovu 1791. godine zapravo je potvrđen status quo. Ovo je imalo dalekosežan utjecaj na djelovanje zaklade koju je Josip II. osnovao. Ona je i dalje ostala namijenjena potrebama Katoličke crkve u Bosni, ali su pravo na njezino korištenje sada preuzeli franjevci Bosne Srebrene i od 1794. godine počeo je sve veći priljev njihovih zavjetovanih novaka. O slanju

47 Ta se opaska nalazi na popisu slušača kanonskoga prava gdje je navedeno: "Restans examen ex historia Ecclesiastica subiverunt. Kordich Theologus $3^{\text {ii }}$ anni Classis $1^{\text {mae". Usp. }}$ NAZ NBS Šk. izv. 6, Classificatio Auditorum Juris Canonici tam ex privatis examinibus qvam et publico ${ }^{i m i}$ Semestris anni 1795/6. reportata. Slično je i u: Isto, Classificatio Auditorum Lingvae Graecae et Hermenvticae Sacrae Novi Testamenti pro primo Semestri Anni Scholastici 1795/6. gdje stoji opaska: "Restantiarii Theologi III. Anni ex Hermenevt. S. V. T. cum Classe ut sequitur, Examen fecerunt. (...) Kordich Georgius I Class."

48 Svi se rezultati ispita nalaze u NAZ NBS Šk. izv. 6.

49 Usp. NAZ III. Protocolla varia, 9b Liber ordinatorum 1752.-1830. U slučaju bosanskih franjevaca učestalom je praksom bilo njihovo ređenje u inozemstvu tijekom boravka na školovanju. Ranije u tekstu spomenuti Dobretić i Kulašević iz Italije su u Zagreb došli kao već zaređeni svećenici. U periodu u kojemu se školovao Kordić u navedenoj knjizi na str. 335-336 ubilježeno je ređenje Paškala Kopića. U kasnijim razdobljima isto je učinio čitav niz drugih franjevaca. Kordić vjerojatno nije mogao primiti svećeničko ređenje, jer s obzirom na dijecezansku pripadnost nije imao dozvolu svoga matičnog biskupa. Opravdano je zaključiti da je svećenički red primio nakon dovršetka novicijata, a da mu ga je podijelio Grgo Ilijić Varešanin koji je 1798. naslijedio teško bolesnog Okića u službi apostolskoga vikara.

50 Podatci o privatnom smještaju sadržani su u jednom izvješću koje je biskup Vrhovac 28. siječnja 1797. podnio KUNV-u, a prema kojemu je gvardijan franjevačkoga samostana u Zagrebu uporno odbijao primiti svjetovne klerike u svoj samostan, iako je to više puta bilo od njega traženo. Usp. NAZ NDS (OD) 100/1797. Int. 
kandidata za dijecezansko svećenstvo više nije moglo biti govora. Habsburška je politika prihvatila novonastalu situaciju, nastojeći zadržati franjevce kao svojevrsnu katoličku kartu u budućim odnosima s Osmanlijskim Carstvom.

Svjetovni klerici su se na taj način $\mathrm{u}$ daljnjem tijeku svoga školovanja suočili s pitanjem kasnije sudbine. Većina ih je odabrala ostanak izvan Bosne, što je za sobom povlačilo ili napuštanje priprave za svećeništvo ili promjenu biskupijske pripadnosti, tj. prelazak u redove svećenstva neke od biskupija na habsburškom području. Među onima koji nisu odustali od svećeničkoga poziva, Kordić je bio prvi koji je dovršio školovanje.

Položivši sve ispite, on se 6. rujna 1797. jednim pismom obratio biskupu $\mathrm{Vr}$ hovcu obavještavajući ga o dovršetku studija i nakani da se vrati u Bosnu. Osnovni motiv ovoga obraćanja je, razumljivo, bilo traženje novčane pomoći. Kordić je naglasio kako je dovršavanjem studija ostao bez iznosa stipendije, a roditelji od kojih je ionako već dugo bio razdvojen, nisu mu bili u mogućnosti išta poslati. Stoga se obraća zagrebačkomu biskupu, moleći ga za financijsku pomoć kako bi se mogao uputiti kući. Biskup Vrhovac je tri dana kasnije ovu zamolbu proslijedio u Budim, preporučujući Namjesničkom vijeću njezino odobrenje. ${ }^{51}$

Kao datum planiranoga polaska Kordić je naveo 5. studenoga. Međutim, prve vijesti o rješavanju njegove zamo- lbe datiraju tek iz ožujka 1798. kada mu je Vijeće napokon na ime putnih troškova dodijelilo svotu od svega 6 $\mathrm{ft}^{52}$ Nezadovoljan time, Kordić se 12. svibnja 1798. novom zamolbom obratio biskupu Vrhovcu, nastojeći obrazložiti svoje potrebe. Spomenutu je svotu ocijenio premalenom, jer se Vijeće prilikom njezina određivanja vodilo nedavnim slučajem Franje Ostojića, jednoga franjevačkog klerika. Kordić je upozorio na to da je Ostojiću taj iznos bio dodijeljen za pokrivanje troškova puta od Požege do Zagreba, dok bi on trebao najprije iz Zagreba putovati u Dalmaciju, zatim do Dubrovnika da bi tek odatle mogao prijeći u Hercegovinu. Posebno je istaknuo činjenicu da od veljače živi na dug jer je ostao bez ikakvih primanja pa bi mu novac trebao već i zbog rješavanja tih novonastalih obveza. U zaključku je ponovio zamolbu da mu se dodijeli $150 \mathrm{ft}$. ili barem polovica toga iznosa. Zagrebački je biskup u svom pismu potvrdio opravdanost svih Kordićevih navoda i ponovno zamolio Vijeće da udovolji njegovu traženju..$^{53}$

Ni ovdje nije bio kraj njegovim poteškoćama. U ljeto iste godine, 6. srpnja, javlja se s još jednom zamolbom protkanom dramatičnim tonom u kojoj uglavnom ponavlja ranije izneseno: put prema kući je veoma dugačak i spojen sa znatnim troškovima koje ne može pokriti ni na koji drugi način nego uz pomoć sa strane; roditelji mu nisu u mogućnosti išta poslati, a više nema ni pravo na stipendiju; uza sve

51 Kordićeva molba i kopija pisma biskupa Vrhovca čuvaju se u NAZ NDS (OD) 1013/1797.

52 Usp. NAZ NDS (OD) 512/1798. Int.

53 Usp. NAZ NDS (OD) 669/1798. 
navedeno zbog produljenoga boravka u Zagrebu upao je u dugove koje sada također mora riješiti. Stoga još jednom moli Duhovni stol da se kod KUNV-a zauzme za rješavanje ovoga problema. $^{54}$

Veoma brzo nakon sastavljanja ove posljednje zamolbe Kordić je dobio odgovor iz Budima koji mu je napokon malo podigao raspoloženje. Duhovni stol je, naime, na svojoj sjednici 13. srpnja 1798. raspravljao i o njegovu slučaju u kojemu su se u međuvremenu odigrali pozitivni pomaci. Među materijalima s te sjednice čuva se još jedan Kordićev dopis datiran $s$ istim datumom u kojemu obavještava Duhovni stol kako je primio rješenje iz Budima kojim mu je na ime putnih troškova povrh već ranije odobrenih 6, dodijeljena još 41 forinta i $40 \mathrm{kraj}$ cara. Sačuvano je i rješenje iz Budima sa spomenutom odlukom KUNV-a datirano 12. lipnja iste godine. Kordić je u svom dopisu izrazio zahvalnost, ali je zamolio da se još riješi pitanje dugova nastalih dok je čekao rješavanje svoga slučaja. Biskup Vrhovac je u zaključku sjednice ponovno preporučio pisanje Vijeću s ciljem usvajanja ovoga traženja. ${ }^{55} \mathrm{O}$ dodjeljivanju novih sredstava povrh više puta spomenutih 6 forinti, Vijeće je posebno pisalo biskupu Vrhovcu i 3. srpnja 1798. o čemu je obavijest u Zagreb stigla točno mjesec dana kasnije. ${ }^{56}$ Tom je prilikom napokon i objašnjeno zbog čega se ovaj slučaj toliko dugo rješavao. Vijeće je priznalo kako je cijelo vrijeme pogrješno pretpostavljalo da Kordić i dalje prima stipendiju, pa je zbog toga smatralo kako su njegovi zahtjevi neopravdani.

Nakon ovih posljednjih vijesti Kordićevo se ime više ne spominje i nije poznato kako je uspio riješiti preostala dugovanja, kao niti točan datum njegova napuštanja Zagreba. Smjer njegova putovanja (na koji je Vijeće imalo određene prigovore) bio je vjerojatno motiviran željom da se posjeti roditeljski dom i nema sumnje u to da se Kordić preko Dalmacije nakon 11 godina provedenih u Zagrebu vratio u Hercegovinu. Nakon toga povukao je sasvim logičan korak i zajedno s Ivanom Alovićem, još jednim bivšim svjetovnim klerikom, 27. studenoga 1798. stupio u novicijat franjevačkoga samostana u Kreševu, gdje je godinu dana kasnije položio vječne zavjete. ${ }^{57}$ Time je simbolički zaključen neuspjeh planova etabliranja svjetovnoga svećenstva u Bosni. Nastavno gledano, najuspješniji svjetovni klerik otišao je u okrilje franjevačke zajednice i unutar nje ostvario zapažen cursus honorum.

Školovanje Jure (fra Petra) Kordića, dakle, istraživačku pažnju više privlači zbog okolnosti u kojima se odvijalo, nego li zbog nekih svojih specifičnosti ili vrhunskih dosega. Kordić je pripadao skupini čije je školovanje predstavljalo pokušaj stvaranja uvjeta za uspostavljanje redovite crkvene hijerarhije u Bosni i Hercegovini. Nje-

54 Usp. NAZ NDS (OD) 837/1798.

55 Svi spomenuti materijali nalaze se u NAZ NDS (OD) 855/1798. Int.

56 Usp. NAZ NDS (OD) 931/1798. Int.

57 Usp. R. Jolić, Novicijat, str. 45-46. 
gov (ne)uspjeh ovisio je o habsburškoj ratnoj sreći u Dubičkom ratu i kada on nije urodio očekivanim plodovima, školovanje ovih klerika izgubilo je velik dio svoga smisla. Štoviše, zbog slabe pripremljenosti ono je od početka bilo praćeno značajnim poteškoćama. To se jasno ogleda i u dostupnim izvorima na osnovi kojih je moguće rekonstruirati poimeničan popis svih klerika koji su bili dio opisanih planova, a da pri tom upravo onaj dio koji je u ovoj fazi trebao biti najznačajniji (njihovo školovanje) ostaje najmanje poznat. U tom je kontekstu Kordićev primjer izrazito značajan, jer premda ne u potpunosti, upravo je tijek njegova školovanja poznat u najvećoj mjeri.

U skladu s tadašnjom praksom, važećom u Habsburškoj Monarhiji, školovanje mu je trebalo trajati 12 godina. Kordić je, ipak, na njemu proveo "samo" deset. Konkretni podatci postoje za posljednjih 5 godina u kojima je dovršio drugu godinu studija filozofije i četiri godine teologije. U ovom periodu nalazi se jedna zanimljivost, jer je Kordić dovršavajući filozofski studij paralelno slušao i dio gradiva prve godine teologije. Uspjeh na ispitima otkriva ga kao predstavnika "zlatne sredine", nije postigao nikakve zapaženije ili posebno istaknute rezultate, ali njegovi profesori zasigurno nisu s njim imali nikakvih izraženijih problema. Uostalom, osrednji uspjeh je velikim dijelom sigurno bio i logičnom posljedicom toga što je Kordić velik dio svoga boravka u Zagrebu proveo upućen sam na sebe, bez adekvatna nadzora i skrbi. Gledano s odmakom, takav se razvoj situacije mogao očekivati još od samoga početka, kada se klerike od- mah po dolasku u Zagreb smjestilo u tamošnji franjevački samostan, a da nisu bile provedene odgovarajuće pripreme. Klerici su ondje naišli u najmanju ruku na hladan prijem i prve su godine za sada poznate samo iz opisa stalnih disciplinskih problema. Kordić se i ovdje smjestio u nekakvu sredinu. Izvori, čak ni oni potekli od protivne strane u sukobima, nikada ga ne apostrofiraju kao krivca, a kamo li kolovođu problema koji su izbijali. Jedini konkretan navod otkriva i njegovu kolegijalnu stranu naravi. Kada se najkasnije ujesen 1793. našao u nuždi pronalaska privatnoga smještaja, to očito nije bilo zbog njegovih osobnih karakteristika, nego zbog njegova nefranjevačkoga statusa. Iz toga razdoblja, na žalost, nije poznato ništa o tijeku njegova školovanja, pa tako ni odgovor na najvažnije pitanje: od kojih je razreda nižih obrazovnih razina bio oslobođen?

Po dovršetku ukupna studija zbog pogrješke u komunikaciji na osnovi koje su mjerodavne institucije stekle pogrješan uvid u njegovo materijalno stanje, Kordić je bio prisiljen produljiti svoj boravak u Zagrebu za skoro punu godinu dana, boreći se za novčani iznos kojim bi pokrio putne troškove. Zahvaljujući podršci i zalaganju biskupa Maksimilijana Vrhovca taj je problem konačno bio riješen i Kordić se vratio kući i stupio u franjevački red. Njegov je redovnički put također prošao slično kao i školski: izrazito sadržajan, ali bez značajnijega isticanja u bilo kojem pogledu.

Osamnaest godina kasnije, kada je prvi put obavljao službu provincijala Bosne Srebrene, Kordić je u jednom pismu upućenu biskupu Vrhovcu 2. 
prosinca 1817. još jednom zahvalio zagrebačkom biskupu: "Živo sam želio sebi naći načina i vremena da uzmognem pisati, izraziti poštovanje i zahvaliti Vašoj Preuzvišenosti za pružena besmrtna dobročinstva iskazana doista očinskom ljubavlju i meni, kada sam nekoć studirao u Zagrebu, i drugim našim pitomcima, što više svima nama. A budući da sam nedostojan umjesto svih njih izraziti zahvalnost, ipak, ne zaboravljajući nikada dobročiniteljâ, žarko ću i stalno s ostalima moliti Oca milosrđa za trajno zdravlje Vaše Premilostive Preuzvišenosti." ${ }^{18}$ To je i jedini pisani trag koji je Kordić sam ostavio o svome školovanju.
Zbog nedovoljna poznavanja biografskih detalja o ostalim pripadnicima skupine svjetovnih klerika, Kordića se ne može sa stopostotnom sigurnošću nazvati prvim Hercegovcem koji je svoje obrazovanje pohađao stipendiran sredstvima zaklade Josipa II. Međutim, sigurno je kako je bio prvi hercegovački klerik koji ga je dovršio. U idućim desetljećima taj će se broj neprestano povećavati i brojni će bivši stipendisti igrati istaknutu ulogu u crkvenom životu bosanskohercegovačkoga prostora, a posebno u podizanju širokobriješkog samostana i osnivanju samostalne franjevačke kustodije, danas provincije Uznesenja Bl. Djevice Marije.

58 Cit. prema NAZ NDS (OD) 2003/1817.: "Vehementer desiderabam obtingere mihi modum, tempusve, quo scribere, obsequi, et gratias agere possem Excellentiae V[es]trae pro praestitis immortalibus beneficiis tum mihi, cum olim Zagrabiae litteris operam navarem, tum aliis Alumnis nostris quin imo omnibus nobis charitate vere paterna exhibitis. Pro quibus omnibus cum sim impar referendo grates Benefactorum tamen haud unquam immemor pro perenni incolumitate suae Excellentiae Gratiosissimae Patrem Misericordiarum fervide cum reliquis constanterque sum exoraturus." 


\section{Education of Jure (Fr. Petar) Kordic}

\section{Summary}

After the Treaty of Belgrade, signed in 1739, the Habsburg foreign politics over the next nearly half a century turned mostly to Western and Central Europe, where in the wars against Prussia they defended the Habsburgs' right of succession to the throne. Meanwhile, the Catholic Church in the Ottoman Bosnia underwent two important processes. The first one was the establishment of the Apostolic Vicariate in Bosnia in 1735, which secured a permanent resident bishop at the territory of Bosnia and Herzegovina, and the other one referred to two divisions of the Franciscan province of Bosnia Argentaria which after 1757 reduced its scope to the area under Ottoman rule. Both of these processes confirmed and even further increased the importance of the Bosnian Franciscans as the main leaders of Catholicism in this area.

Among many challenges that the Franciscans faced with, one of the most important was the the education of their own clerics. Difficult material circumstances turned Bosnia Argentaria to the help from abroad. Clerics were sent to the Franciscan province in Italy, which was only a partial solution. Joseph II of Habsburg once again turned the direction of foreign expansion to the Ottoman Empire, trying to include the Bosnian Franciscans into his plans. He secured the election of Augustin Botos Okic as the apostolic vicar and gained his support, creating a promising solution to the problem of education of future pastoral workers for the $\mathrm{BH}$ territory, the purpose of which was the establishing of financial fund. The original plan was to use its assets to create a secular clergy, independent of Bosnia Argentaria, on whose basis they would begin to build regular church hierarchy. With this intention in the eve of Dubica War (1788 to 1791) eleven Bosnian boys were sent to Zagreb (later joined by one more), among whom was Jure Kordic from Sretnice in the then vast parish of Brotnjo. The war that Joseph II led against the Ottomans did not result in territorial expansion, and the plans about sending secular clergy to Bosnia were not implemented.

Consequently, the education of secular clerics turned into a sort of fiasco, because most of them neither became priests nor returned to Bosnia. Their stay in Zagreb was characterized by frequent disciplinary problems and constant dissipati- 
on of the group. Kordic was an exception for several reasons. Firstly, he was one of the two clerics who eventually returned to Bosnia where they entered the Franciscan order, and secondly, he was the first among them to complete the entire education. Finally, Kordic was the only one whose flow of education could be, at least to some extent, reconstructed concerning its content and time, especially the last phase when he attended the study of theology.

Under missionary name of Peter, this cleric would later achieve a noteworthy career, during which he carried the duty of the provincial minister of Bosnia Argentaria on two occasions. However, in the entire history of the province he deserved his place for being among first Bosnian clerics who received the scholarship by the Habsburg authorities, which was a process that had a tremendous impact on the later history of Bosnia and Herzegovina.

Keywords: Jure (Fr. Peter) Kordic, bishop's lycee, Zagreb, Joseph II fund; study of theology. 